\title{
PENGARUH PERSEPSI KUALITAS, HARGA, REPUTASI PERUSAHAAN DAN KEPUASAN PELANGGAN TERHADAP PENGAMBILAN KEPUTUSAN PEMBELIAN JASA PENERBANGAN LION AIR PADA PT. VINA TOUR \& TRAVEL MEDAN
}

\author{
Roslinda Sagala \\ Universitas Katolik Santo Thomas Medan Jl. Setia Budi No. 479F, 20132, Indonesia \\ e-mail: sagalaroslinda@yahoo.com.id
}

\begin{abstract}
The purpose of this study analyzed the influence of perceptions of quality, price, corporate reputation and customer satisfaction partially and simultaneously to the decision to purchase airline services. Benefits Research, provide empirical evidence on the influence of variables that can influence purchasing decisions from consumers and provide solutions in the form of suggestions on the management of these variables. For the community. provide knowledge to the public especially for those who want to be involved in the business world and related to the business of maintaining the brand and maintain the existence of customers. For education, it gives academic contribution to the importance of managing variables that can influence consumer purchasing decisions through the perception of quality, price, company reputation and customer satisfaction. Number of sample 96 respondents, data collection method through questioner and documentation, method of data analysis with multiple regression. Result of regression equation: $P K P=12,034+.624 P K 0,873 \mathrm{H}+0,505 R P+.705 \mathrm{KP}$. . meaning that the perception variable of quality, price, reputation of company and customer satisfaction have positive influence to decision of purchasing service of flight. Of the four variables that are more influential on the decision to purchase airline services are price variables and customer satisfaction. The correlation coefficient of perception variable of quality, price, reputation of company and customer satisfaction to decision of purchasing service of aviation have very strong relation with value value $r=0,843$. The determinant coefficient of $r 2=0,710629$, meaning variable variable of perception of quality, price, company reputation and customer satisfaction can explain $71,06 \%$ to decision of purchasing service of flight, while 28,94\% influenced by other factors. Based on $t$ test, the value of $t$ count the fourth variable $>t$ table means partially the four independent variables have a significant influence on the decision to purchase airline services. With the F test, the value of F arithmetic (Variable perception of quality, price, company reputation and customer satisfaction) $>F$ table, meaning that simultaneously the variable has a significant influence on the decision to purchase airline services. Based on the results of research, the company should improve the perception of quality through improving the quality of service and reputation of the company through the improvement of the attributes offered through its products. Customer satisfaction and price become the center of attention from customers, then the management should still be able to maintain it for the sake of the survival of PT. Vina Tour \& Travel Medan in the future.
\end{abstract}

Keywords: Perception Quality, Price, Reputation Company, Customer Satisfaction and Buying decision

\section{PENDAHULUAN}

Dewasa ini persaingan dunia bisnis jasa semakin ketat dengan adanya kemajuan teknologi komunikasi dan informasi sehingga konsumen mempunyai informasi yang lengkap mengenai alternatif pilihan produk/jasa yang tersedia di pasar. Para produsen atau penjual berusaha memenuhi kebutuhan dan keinginan serta memberikan kepuasan secara maksimal kepada konsumen. Freenan dan Dart dalam Puspitasari (2006) mengemukakan bahwa kinerja pelayanan yang tinggi merupakan hal yang sangat mendasar bagi kelangsungan hidup suatu perusahaan jasa. Pelayanan yang berkinerja tinggi adalah pelayanan yang mampu 
memberikan kepuasan terhadap kebutuhan pelanggan atau mampu melebihi harapan pelanggan (Anderson, Fornell, dan Lehmann, 1994).

Tujuan umum dari hubungan pemasaran adalah untuk membangun dan mempertahankan pelanggan yang dapat menguntungkan perusahaan (Zeithaml dan Bitner, 1996). Pelanggan merupakan aset yang memegang peranan penting untuk menentukan keberhasilan perusahaan. Mengingat pelanggan mampu mencerminkan potensi pertumbuhan perusahaan dimasa mendatang maka upaya untuk menciptakan dan mempertahankan pelanggan menjadi prioritas utama bagi perusahaan.

Konsep kepuasan konsumen merupakan hal penting bagi para manajer pemasaran dimana kepuasan konsumen dapat mendorong pembelian ulang (Fornell, 1992). Kepuasan konsumen merupakan aset yang penting bagi perusahaan karena dapat digunakan sebagai indikator atas kualitas dan pendapatan perusahaan dimasa mendatang. Kepuasan pelanggan merupakan hasil dari perbandingan antara harapan dan kenyataan yang diterima pelanggan setelah mengkonsumsi barang atau jasa. Berkaitan dengan kesetiaan pelanggan, Anderson, Fornell, dan Lehmann (1994) menyatakan bahwa apabila pelanggan puas terhadap barang atau kualitas layanan yang diberikan maka akan timbul kesetiaan pelanggan sehingga minat beli pelanggan meningkat dan membuat pelanggan kembali melakukan pembelian ulang (repurchase). Pelanggan yang puas disebut sebagai retained customers sedangkan pelanggan yang tidak puas adalah lost customers. Pelanggan yang bertahan (retained customers) memiliki peranan penting dalam persaingan bisnis yang ketat bagi pencapaian performa bisnis yang tinggi (Crane dalam Puspitasari, 2006). Sehingga strategi kualitas pelayanan yang mampu meningkatkan jumlah pelanggan yang bertahan (customers retained rate) menjadi fokus utama dalam era persaingan bisnis jasa yang ketat. Oleh karena itu, PT. Lion Air sebagai entitas bisnis jasa yang bergerak dalam industri jasa penerbangan sudah semestinya berorientasi kepada kualitas layanan dan kepuasan pelanggan karena pelanggan yang puas merupakan salah satu aset penting untuk kelangsungan hidup dan perkembangan bisnis itu sendiri. Pengelolaan strategi-strategi yang tepat untuk menarik pelanggan perlu direncanakan secara matang agar pelanggan mau membeli produk atau jasa yang dihasilkan oleh perusahaan. Selain itu perusahaan juga perlu untuk terus berupaya agar konsumen dapat menjadi pelanggan yang loyal.

Fenomena yang terjadi saat ini yaitu adanya perang harga (budget airline/terbang murah) dari maskapai-maskapai baru yang memperlihatkan kualitas layanannya berupa perluasan segmen. Dalam rangka meningkatkan kualitas pelayanan dan kenyamanan penumpang, PT. Lion Air telah menambah armadanya dengan pesawat-pesawat yang lebih canggih dan nyaman. Dari penelitian pendahuluan yang telah dilakukan memberikan respon dari pelanggan bahwa harga tiket yang cenderung mengalami peningkatan tetap mereka bayar karena tingkat kepercayaan masyarakat terhadap pelayanan jasa penerbangan PT. Lion Air yang semakin tinggi sehingga mereka merasa aman dalam melakukan perjalanan. Hal tersebut selaras dengan penelitian yang telah dilakukan oleh Brown dan Dacin (1997) dimana reputasi perusahaan sangat penting dari sudut pandang pelanggan untuk memberikan gambaran terhadap kualitas produk atau jasa yang dihasilkan, dimana harga yang tinggi dari suatu merek seringkali dipersepsikan memiliki kualitas yang tinggi (Chapman dan Wahlers, 1999). Seperti dikemukakan oleh para peneliti dalam Hellier, Geursen, Carr, dan Rickard (2003) dikatakan bahwa kepuasan pelanggan secara keseluruhan pada layanan jasa berasosiasi kuat terhadap perilaku konsumen untuk menggunakan kembali jasa dari penyedia yang sama. Zeithaml (1988) mengidentifikasikan persepsi kualitas sebagai komponen dari nilai merek dimana persepsi kualitas yang tinggi akan mengarahkan konsumen untuk memilih merek tersebut dibandingkan dengan merek pesaing.

Persepsi kualitas yang dirasakan oleh konsumen berpengaruh terhadap kesediaan konsumen tersebut untuk membeli sebuah produk (Chapman dan Wahlers, 1999). Persepsi kualitas jasa dengan lima dimensi kualitas jasa berhubungan positif terhadap minat beli ulang 
pelanggan (Li dan Lee, 2001). Parasuraman, Zeithaml, dan Berry $(1985,1988)$ mengemukakan bahwa terdapat hubungan positif secara langsung antara persepsi kualitas dengan minat beli ulang. Penelitian ini terfokus pada Pengaruh Persepsi Kualitas, Harga, Reputasi Perusahaan dan Kepuasan Pelanggan Terhadap Pengambilan Keputusan Pembelian Jasa Penerbangan ( Studi Kasus : Pelanggan Jasa Penerbangan PT. Lion Air). Penelitian ini hampir sama dengan dengan penelitian sebelumnya, persamaannya menggunakan empat variabel bebas dan perbedaannya pada variabel terikatnya. Variabel terikat pada variabel sebelumnya yaitu minat membeli ulang.

Berdasarkan latar belakang tersebut diatas maka perumusan masalah dalam penelitian ini adalah bagaimana mempertahankan pelanggan ditengah fenomena perang harga, persepsi kualitas, reputasi perusahaan dan kepuasan pelanggan sebagai variabel pendahulunya. Maka perumusan masalah dalam penelitian ini : Bagaimana Pengaruh persepsi kualitas, harga, reputasi perusahaan dan kepuasan pelanggan secara parsial dan simultan terhadap pengambilan keputusan pembelian jasa penerbangan Lion Air Pada PT. Vina Tour \& Travel Medan?

\section{TINJAUAN PUSTAKA}

\section{A. Pengertian Pemasaran}

Pemasaran merupakan salah satu elemen pokok yang wajib dimiliki oleh setiap perusahaan. Pemasaran berkaitan erat dengan bagaimana cara perusahaan dapat berhubungan atau berinteraksi dengan pangsa pasar atau konsumen, yang pada akhirnya pangsa pasar atau konsumen akan tertarik untuk membeli produk yang ditawarkan perusahaan dan menghasilkan laba bagi perusahaan. Berikut ini beberapa pengertian dari para ahli mengenai pemasaran.

Menurut Stantondalam Hazali (2012), definisi pemasaran adalah suatu sistem keseluruhan dari kegiatan-kegiatan bisnis yang ditujukan untuk merencanakan, menentukan harga, mempromosikan dan mendistribusikan barang atau jasa yang memuaskan kebutuhan baik kepada pembeli yang ada maupun pembeli potensial. Dalam bukunya yang lain, Kotler (2007:6) mendefinisikan pemasaran suatu proses sosial yang didalamnya individu dan kelompok mendapatkan apa yang mereka butuhkan dan inginkan dengan menciptakan, menawarkan, dan secara bebas mempertukarkan produk yang bernilai dengan pihak lain.

Dari kedua definisi diatas kita dapat melihat bahwa inti dari pemasaran tersebut adalah bagaimana cara untuk dapat memenuhi kebutuhan dari pihak pihak lain, baik pihak pembeli yang ada maupun pembeli potensial yang dilakukan melalui kegiatan pemasaran. Semua itu dilakukan untuk memberikan kepuasan kepada pangsa pasar atau konsumen yang dipilih.

\section{B. Pengertian Bauran Pemasaran}

Berikut ini pengertian dari bauran pemasaran (Marketing Mix) menuru para ahli:

1. Menurut Kotler (2005:19) “Bauran Pemasaran adalah seperangkat alat pemasaran yang digunakan perusahaan untuk terus menerus mencapai tujuan pemasaran di pasar sasaran"

2. Menurut Murti Sumarni (2002:246) "Bauran Pemasaran adalah kombinasi dari empat variabel/kegiatan yang merupakan inti dari sistem pemasaran yaitu produk, harga, promosi dan distribusi. Atau dapat dikatakan bahwa bauran pemasaran merupakan satu perangkat yang akan menentukan tingkat keberhasilan pemasaran dan semua itu ditunjukan untuk memberikan kepuasan kepada pangsa pasar atau konsumen yang dipilih.

Guna mencapai tujuan pasar telah ditargetkan maka perusahaan harus menggunakan variable-variabel pemasaran yang dapat dikendalikan. Philip Kotler dan Gary Amstrong (2004:320) mengemukakan bauran pemasaran terbagi atas empat variabel sebagai berikut : 


\section{Produk.}

Di dalam kondisi persaingan, sangatlah berbahaya bagi sebuah perusahaan bila hanya mengandalkan produk tanpa usaha untuk mengembangkannya. Oleh karena itu di dalam mempertahankan dan meningkatkan penjualan dan market share perlu mengadakan penyempurnaan dan pengembangan produk yang di hasilkan lebih baik, sehingga dapat memberikan daya guna, daya pemuas, serta daya tarik yang lebih besar. Strategi produk dalam hal ini adalah menetapkan cara dan menyediakan produk yang lebih tepat bagi pasar yang dituju, sehingga dapat memuaskan konsumen dan sekaligus dapat meningkatkan keuntungan perusahaan dalam jangka panjang, melalui peningkatan penjualan dan peningkatan marker sharenya. Dalam marketing mix, strategi produk merupakan unsur penting karena dapat mempengaruhi strategi pemasaran lainnya. Pemilihan jenis produk yang akan di hasilkan dan di pasarkan akan menentukan kegiatan promosi yang dibutuhkan serta penentuan harga serta cara penyalurannya Tujuan utama strategi produk adalah untuk mencapai sasaran pasar yang dituju guna meningkatkan kemampuan bersaing atau mengatasi persaingan. Oleh karena itu strategi produk merupakan strategi pemasaran, sehingga gagasan atau ide untuk melakukan harus datang dari bidang pemasaran.

\section{Price (harga)}

Harga merupakan satu- satunya unsur marketing mix yang menghasilkan penerimaan penjualan, sedangkan unsur lainnya merupakan unsur biasa saja. Meskipun penetapan harga merupakan persoalan yang penting, namun masih banyak perusahaan yang kurang mampu menangani permasalahan penetapan harga yang dapat mempengaruhi penerimaan perusahaan, sebab harga dapat mempengaruhi tingkat penjualan yang mana berdampak pada keuntungan serta market share yang dicapai oleh perusahaan. Penetapan harga akan menjadi sangat penting terutama pada keadaan persaingan yang semakin tajam dan perkembangan permintaan. Persaingan yang semakin tajam dewasa ini sangat terasa dalam pasar pembeli (buyer market) peranan harga sangat penting terutama untuk menjaga dan meningkatkan posisi perusahaan di pasar yang tercermin dalam target pasar perusahaan. Dengan kata lain, penetapan harga mempengaruhi kemampuan bersaing perusahaan dan kemampuan mengenai konsumen.

\section{E. Distribusi}

Distribusi merupakan kegiatan penyampaian produk dari produsen ke konsumen pada waktu yang tepat. Oleh karena itu distribusi merupakan salah satu kebijakan pemasaran yang mencakup penentuan saluran pemasaran (marketing channels) dan distribusi fisik (physical distribution). Bagaimanapun bagusnya suatu produk baik dari segi kualitas, model, serta harga yang terjangkau, tidak akan berarti sama sekali apabila konsumen sama sekali tidak mengetahui tentang produk tersebut, serta tidak mengetahui dimana bisa mendapatkan informasi mengenai produk tersebut. Oleh karena itu diperlukan lembaga-lembaga perantara untukmenghubungkan perusahaan dengan konsumen. Dengan lembaga-lembaga tersebut akan terbentuk saluran distribusi.

Promosi

Suatu produk bagaimanapun bermanfaatnya jika tidak dikenal konsumen maka produk tersebut tidak akan diketahui dan bermanfaat bagi konsumen. Oleh karena itu perusahaan harus melakukan cara agar konsumen dapat mengetahui produk perusahaan tersebut. Serta berusaha mempengaruhi konsumen untuk dapat menciptakan permintaan atas produk tersebut, kemudian dipelihara dan dikembangkan. Usaha tersebut dapat dilakukan dengan melakukan rangkaian kegiatan promosi sebagai salah satu acuan pemasaran. Kegiatan promosi dilakukan sejalan dengan rencana pemasaran secara keseluruhan serta direncanakan akan diarahkan dan dikendalikan dengan baik, diharapkan akan dapat berperan secara baik dalam meningkatkan penjualan dan market share. 


\section{F. Pengertian Perilaku Konsumen}

Pemahaman mengenai masalah pemasaran khususnya tentang usaha untuk memenuhi kebutuhan dan keinginan konsumen, perusahaan harus memahami tentang perilaku konsumen.

Menurut Lamb dkk., (2001:188), “perilaku konsumen adalah proses seseorang konsumen dalam membuat keputusan membeli, untuk menggunakan dan membuang barang-barang dan jasa yang dibeli, juga termasuk faktor-faktor yang mempengaruhi keputusan pembelian dan penggunaan produk". Menurut Setiadi (2005:3), "perilaku konsumen merupakan interkasi dinamis antara afeksi dan kognisi, perilaku, dan lingkungannya dimana manusia melakukan kegiatan pertukaran dalam hidup mereka".

Berdasarkan pengertian di atas, terdapat tiga hal penting, yaitu perilaku konsumen adalah dinamis, perilaku konsumen melibatkan interaksi dan perilaku konsumen melibatkan pertukaran. Perilaku konsumen memiliki kepentingan khusus karena berhasrat mempengaruhi atau mengubah perilaku konsumen, termasuk mereka yang kepentingan utamanya adalah pemasaran, pendidikan dan perlindungan konsumen.

Perilaku konsumen dinamis berarti seorang konsumen, grup konsumen serta masyarakat luas selalu berubah dan bergerak sepanjang waktu. Perubahan tersebut, berpengaruh terhadap studi perilaku konsumen dan pengembangan strategi pemasaran. Dalam studi perilaku konsumen, salah satu implikasinya adalah bahwa generalisasi perilaku konsumen biasanya terbatas untuk satu jangka waktu tertentu, produk dan individu serta grup tertentu.

Dalam pengembangan strategi pemasaran, sifat dinamis perilaku konsumen menyiratkan bahwa seseorang tidak boleh berharap bahwa suatu strategi pemasaran yang sama dapat memberikan hasil yang sama di sepanjang waktu, pasar dan industri. Walaupun hal ini tampak sederhana, namaun banyak perusahaan gagal menyadari kebutuhan untuk mengantisipasi strategi pemasaran di pasar yang berbeda.

Perilaku konsumen melibatkan interaksi berarti untuk memahami konsumen dan mengembangkan strategi pemasaran yang tepat, perlu memahami apa yang dipikirkan oleh konsumen (kognisi), apa yang mereka rasakan (pengaruh), apa yang mereka lakukan (perilaku), apa serta dimana (kejadian di sekitar) yang mempengaruhi serta dipengaruhi oleh apa yang dipikirkan, dirasakan dan dilakukan konsumen. Di sini, bisa hanya menganalisis dampak kejadian di sekitar terhadap pengaruh, kognisi dan perilaku seperti yang biasa dilakukan dalam riset pasar. Akan tetapi, dalam mengevaluasi seorang konsumen, pasar sasaran atau keseluruhan masyarakat. Analisis ketiga elemen tersebut sangat berguna untuk memahami dan mengembangkan stategi pemasaran.

Perilaku konsumen melibatkan pertukaran berarti definisi perilaku konsumen tetap konsisten dengan defenisi pemasaran yang menekankan pertukaran. Pemasaran berperan untuk menciptakan pertukaran dengan konsumen melalui formulasi dan penerapan strategi pemasaran. Perilaku konsumen bersifat kompleks karena setiap konsumen mempunyai kebutuhan dan keinginan yang berbeda-beda, selalu berubah-ubah sehingga dapat disimpulkan bahwa perilaku konsumen secara umum adalah tindakan yang dilakukan individu, kelompok atau organisasi yang berhubungan dengan proses mental dan emosional dalam pengambilan keputusan untuk mendapatkan, menggunakan barang-barang atau jasa yang dapat memuaskan keinginan dan kebutuhannya.

\section{G. Persepsi Kualitas}

Persepsi kualitas (perceived quality) menurut Aaker (1997) dapat didefinisikan sebagai persepsi pelanggan terhadap keseluruhan kualitas atau keunggulan suatu produk atau jasa layanan berkaitan dengan apa yang diharapkan oleh pelanggan. Aaker (1997) menegaskan satu hal yang harus selalu diingat, yaitu bahwa persepsi kualitas merupakan persepsi para 
pelanggan, oleh sebab itu persepsi kualitas tidak dapat ditetapkan secara obyektif. Selain itu, persepsi pelanggan akan melibatkan apa yang penting bagi pelanggan karena setiap pelanggan memiliki kepentingan yang berbeda-beda terhadap suatu produk atau jasa .

Maka dapat dikatakan bahwa membahas persepsi kualitas berarti akan membahas keterlibatan dan kepentingan pelanggan. Persepsi kualitas yang tinggi menunjukkan bahwa melalui penggunaan dalam jangka waktu yang panjang, konsumen memperoleh diferensiasi dan superioritas dari merek tersebut. Zeithaml mengidentifikasikan persepsi kualitas sebagai komponen dari nilai merek dimana persepsi kualitas yang tinggi akan mengarahkan konsumen untuk memilih merek tersebut dibandingkan dengan merek pesaing. Persepsi kualitas yang dirasakan oleh konsumen berpengaruh terhadap kesediaan konsumen tersebut untuk membeli sebuah produk. Ini berarti bahwa semakin tinggi nilai yang dirasakan oleh konsumen, maka akan semakin tinggi pula kesediaan konsumen tersebut untuk akhirnya membeli (Chapman dan Wahlers, 1999). Persepsi kualitas mencerminkan perasaan pelanggan yang tidak Nampak dan secara menyeluruh mengenai suatu merek. Akan tetapi, biasanya persepsi kualitas didasarkan pada dimensi-dimensi yang termasuk dalam karakteristik produk tersebut dimana merek dikaitkan dengan hal-hal seperti keandalan dan kinerja. Lima dimensi kualitas jasa (Parasuraman, Zeithaml, dan Berry, 1988; Zeithaml et al, 1996) yang dipergunakan untuk memahami harapan dan persepsi konsumen terhadap kualitas jasa tersebut adalah :

1. Keandalan (Reliability). Kemampuan untuk melaksanakan jasa yang dijanjikan dengan tepat dan terpercaya.

2. Ketanggapan (Responsiveness). Kemauan perusahaan untuk membantu pelanggan dan memberikan jasa dengan cepat.

3. Keyakinan (Assurance). Pengetahuan dan keramahtamahan para karyawan serta kemampuan mereka untuk menimbulkan kepercayaan dan keyakinan.

4. Empati (Empathy). Syarat untuk peduli, memberi perhatian pribadi bagi pelanggan.

5. Berwujud (Tangibles). Penampilan fasilitas fisik (interior dan eksterior), peralatan, karyawan, dan media komunikasi.

Berdasarkan pada penelitian-penelitian tersebut diatas maka variabel persepsi kualitas dapat dibentuk dari lima indikator, yaitu keandalan, ketanggapan,keyakinan, empati dan berujud.

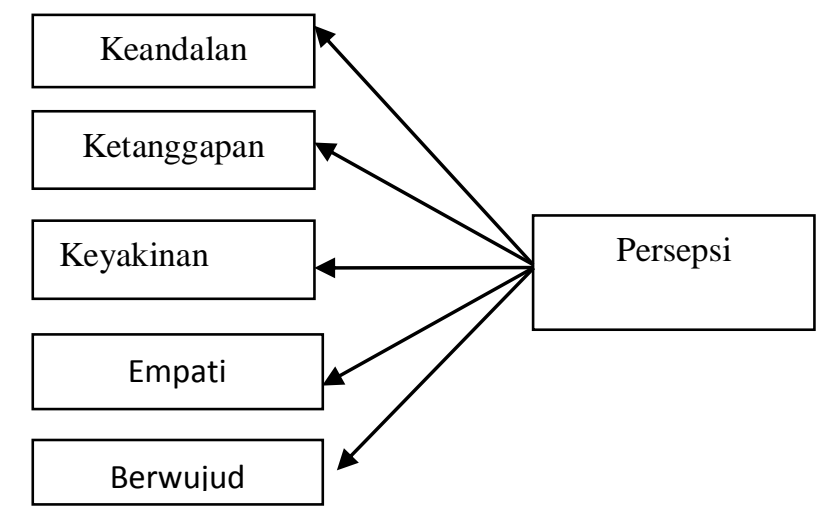

Gambar 1. Indikator-indikator Persepsi Kualitas

Sumber : Parasuraman et al. (1988) dan Zeithaml et al. (1996) dikembangkan dalam penelitian ini.

\section{H. Harga}

Harga merupakan besarnya pengorbanan yang dilakukan oleh konsumen untuk memperoleh sebuah produk atau jasa yang dibutuhkan (Zeithaml, 1988). Stedman (2000) mengidentifikasikan bahwa harga merupakan salah satu factor penting yang dapat mempengaruhi perilaku konsumen dalam pembelian merek, karena suatu barang atau jasa 
pastilah mempunyai nilai. Sedangkan nilai itu sendiri didasarkan dari harga, yang merupakan tolak ukur dari barang maupun jasa yang bersangkutan. Kennedy (1994) mengemukakan bahwa penjualan produk berkualitas tinggi kemungkinan dapat ditandai berdasarkan harga yang tinggi pula. Konsumen seringkali menggunakan harga sebagai petunjuk ekstrinsik atau indikator dari kualitas ataupun manfaat suatu produk. Hasil dari beberapa penelitian mengemukakan bahwa harga yang tinggi dari suatu merek seringkali dipersepsikan memiliki kualitas yang tinggi dan tidak peka terhadap persaingan potongan harga seperti merekmerek dengan harga yang rendah (Yoo, Donthu, dan Lee, 2000). Harga yang tinggi dapat menimbulkan persepsi kualitas produk atau jasa yang tinggi pula dari suatu merek (Monroe, 1973 dalam Ward, Chitty, and Achard, 2005; Dodds, Grewal, dan Monroe, 1991). Dalam penelitiannya, Ward, Chitty, and Achard (2005) mengukur persepsi harga dari konsumen dengan perkiraan besarnya harga yang bersedia dibayar oleh mereka untuk tiap merek terlibat. Teknik tersebut juga digunakan oleh Al-Sabbahy, Ekinci, dan Riley (2004) menilai persepsi responden terhadap kewajaran harga yang harus dibayar beradasarkan internal feeling dan pengetahuan mereka atas harga dari penyedia jasa lainnya pada bidang yang sama.

Menurut Kotler (2001) dalam membuat keputusan mengenai harga harus memperhatikan atau harga sangat dipengaruhi oleh :

1. Konsumen sasaran. Apabila konsumen sasaran suatu perusahaan adalah konsumen tingkat atas maka perusahaan akan cenderung menetapkan harga yang tinggi.

2. Permintaan konsumen. Jika terjadi permintaan yang cukup tinggi terhadap suatu produk dan jumlah barang yang tersedia sedikit maka perusahaan cenderung menetapkan harga cukup tinggi.

3. Pesaing . Jika dalam suatu pasar terdapat banyak pesaing yang menjual produk yang sejenis, produsen akan menetapkan harga yang rendah atau bersaing.

Berdasarkan pada penelitian-penelitian tersebut diatas maka variabel harga dapat dibentuk dari tiga indikator, yaitu perkiraan harga, kesesuaian pengorbanan, dan kewajaran harga.

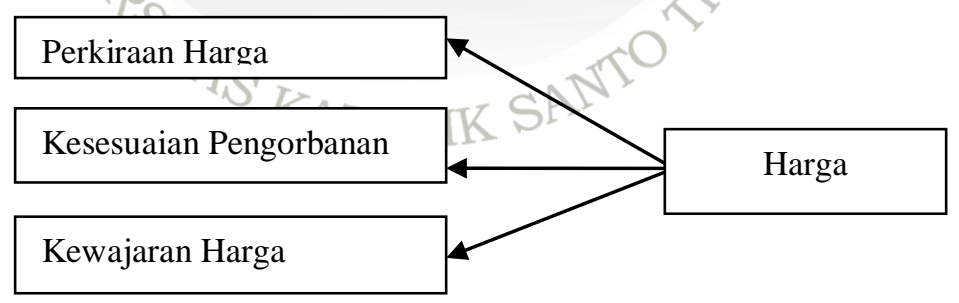

Gambar 2. Indikator-indikator Harga

Sumber : Ward, Chitty, dan Achard (2005); Al-Sabbahy, Ekinci, dan Riley (2004) Zeithaml (1988) dikembangkan dalam penelitian ini

\section{Reputasi Perusahaan}

Zeithaml (1988) mengemukakan bahwa kualitas yang dirasakan dari suatu produk atau jasa erat hubungannya dengan reputasi yang diasosiasikan dengan nama merek. Herbig, Milewicz dan Golden (1994) menyatakan bahwa reputasi perusahaan dapat dilihat dari kompetensi perusahaan tersebut dan keunggulan dibandingkan dengan kompetitor nya. Moorman dan Minner (1997) menyatakan bahwa keberhasilan perusahaan secara maksimal dapat dicapai apabila perusahaan tersebut fokus terhadap core business, sebab hal itu akan merefleksikan core competencies yang mereka punyai. Keahlian perusahaan tercermin dalam pengetahuan dan pengalaman perusahaan tersebut dalam industri yang dimasukinya (Brown dan Dacin, 1997; Moorman dan Miner, 1997). Menurut Brown dan Dacin (1997) reputasi perusahaan sangat penting dari sudut pandang pelanggan untuk memberikan gambaran terhadap kualitas produk atau jasa yang dihasilkan. Reputasi dari perusahaan dalam sudut pandang pelanggan dapat dijadikan jaminan bagi pelanggan untuk menilai kualitas produk 
atau jasa Berdasarkan pernyataan-pernyataan tersebut maka variabel reputasi perusahaan dibentuk oleh tiga indikator, yaitu pengalaman perusahaan dalam industri yang dimasukinya, kompetensi perusahaan, dan keunggulan perusahaan dibanding kompetitor.

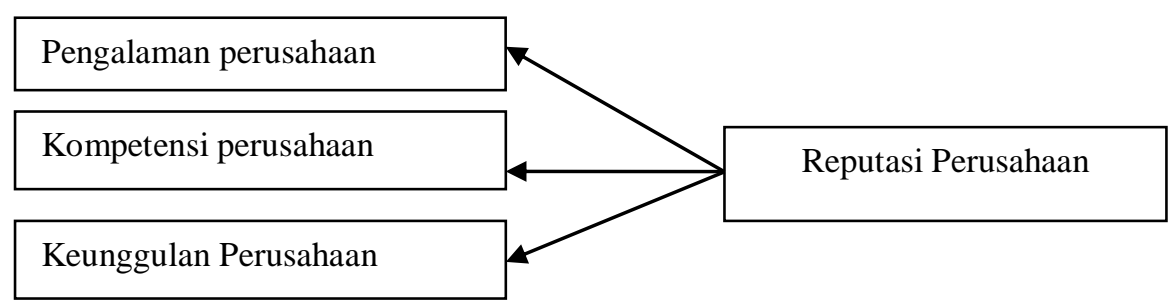

Gambar 3. Indikator-indikator Reputasi Perusahaan

Sumber : Herbig, Milewicz dan Golden (1994); Brown dan Dacin (1997) dikembangkan dalam penelitian ini

\section{J. Kepuasan Pelanggan}

Inti kepuasan merupakan suatu tingkat perasaan pelanggan yang diperoleh setelah menikmati sesuatu. Kepuasan pelanggan didefinisikan sebagai semua sikap berkenaan dengan barang atau jasa setelah diterima dan dipakai, dengan kata lain bahwa kepuasan (satisfaction) adalah pilihan setelah evaluasi penilaian dari sebuah transakasi yang spesifik (Cronin \& Taylor, 1992). Cronin dan Taylor (1994) dalam penelitiannya berhasil membuktikan bahwa kepuasan pelanggan ditentukan oleh penilaian pelanggan terhadap kualitas pelayanan yang diberikan. Kepuasan pelanggan menurut Spreng, Mackenzie \& Olshavsky (1996) akan dipengaruhi oleh harapan, persepsi kinerja, dan penilaian atas kinerja produk atau jasa yang dikonsumsi. Terdapat korelasi positif yang kuat antara persepsi kinerja terhadap kepuasan pelanggan (Anderson, Fornell, dan Lehmann, 1994; Anderson dan Sullivan, 1993). Oliver (1993) menyatakan bahwa kepuasan merupakan tingkat perasaan seseorang setelah membandingkan kinerja atau hasil yang dirasakannya dengan harapan. Tse dan Wilton (1988) menyatakan bahwa kepuasan atau ketidakpuasan pelanggan adalah merupakan respon pelanggan terhadap evaluasi ketidaksesuaian yang dirasakan antara harapan sebelumnya dan kinerja aktual produk setelah pemakaiannya. Oliver (1993) meneliti mengenai kepuasan konsumen yang menunjukkan adanya pengaruh positif antara pengalaman pembelian sebelumnya terhadap tingkat kepuasan. Dengan adanya pengalaman terhadap pembelian sebelumnya kemungkinan hanya sedikit ketidaksesuaian antara harapan dan kinerja serta kemungkinan kecil terhadap ketidakpuasan. Berdasarkan pengalaman yang diperolehnya, pelanggan memiliki kecenderungan untuk membangun nilainilai ekspektasi tertentu. Nilai ekspektasi tersebut akan memberikan dampak bagi pelanggan untuk melakukan perbandingan terhadap kompetitor dari produk yang pernah dirasakannya. Secara langsung penilaian tersebut akan mempengaruhi pandangan dan penilaian pelanggan terhadap perusahaan kompetitor. Berdasarkan hal-hal tersebut maka variabel kepuasan pelanggan dapat dibentuk dari tiga indikator, yaitu kesesuaian harapan, persepsi kinerja, dan penilaian pelanggan.

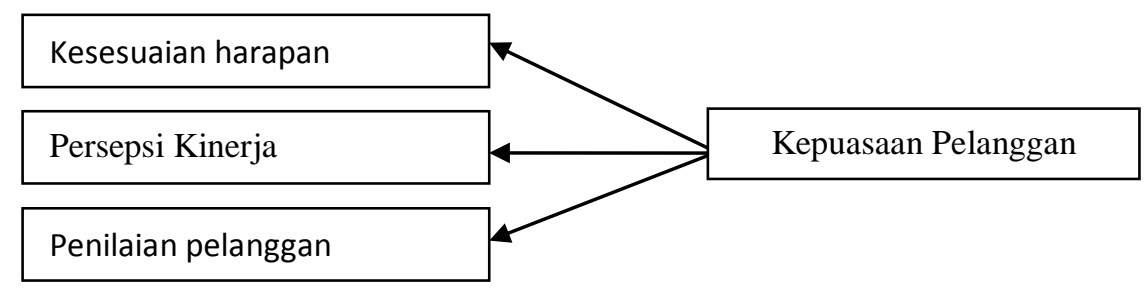

Gambar 4. Indikator-indikator Kepusan Pelanggan

Sumber : Spreng, Mackenzie \& Olshavsky (1996) dikembangkan dalam penelitian ini 


\section{K. Faktor-faktor yang Mempengaruhi Kepuasan Pelanggan}

Fokus kualitas pelayanan terletak pada kepuasan pelanggan, maka perlu dipahami komponen-komponen yang berkaitan dengan kepuasan pelanggan tersebut. Menurut Lupiyoadi (2007:150), ada lima faktor utama yang perlu dipertahankan perusahaan dalam upaya memuaskan pelanggannya adalah:

1. Kualitas produk. Pelanggan akan merasa puas bila hasil evaluasi mereka menunjukkan bahwa produk yang mereka gunakan berkualitas. Pelanggan rasional selalu menuntut produk yang berkualitas untuk setiap pengorbanan yang dilakukan untuk memperoleh produk tersebut. Dalam hal ini, kualitas produk yang baik akan memberikan nilai tambah di benak pelanggan.

2. Kualitas pelayanan. Kualitas pelayanan terutama dibidang jasa, pelanggan akan merasa puas bila mereka mendapatkan pelayanan yang baik atau yang sesuai dengan yang diharapkan. Pelanggan yang puas akan menunjukkan kemungkinan untuk kembali membeli produk yang sama. Pelanggan yang puas cenderung akan memberikan persepsi positif terhadap produk perusahaan.

3. Emosional. Pelanggan akan merasa bangga dan mendapatkan keyakinan bahwa orang lain akan kagum terhadap dia bila menggunakan produk dengan merek tertentu yang cenderung mempunyai tingkat kepuasan yang lebih tinggi. Kepuasan yang diperoleh bukan karena kualitas dari produk tetapi nilai sosial atau self esteem yang membuat pelanggan menjadi puas terhadap merk tertentu.

4. Harga. Produk yang mempunyai kualitas yang sama tetapi menetapkan harga yang relatif murah akan memberikan nilai yang lebih tinggi kepada pelanggannya. Dengan demikian, dapat dikatakan bahwa harga merupakan sejumlah uang yang dikorbankan oleh pelanggan untuk mendapatkan produk.

5. Biaya. Pelanggan tidak perlu mengeluarkan biaya tambahan atau tidak perlu membuang waktu untuk mendapatkan suatu produk atau jasa cenderung puas terhadap produk atau jasa itu.

Kepuasan atau ketidakpuasan pelanggan pada produk akan mempengaruhi tingkah laku berikutnya. Jika pelanggan merasa puas, maka ia akan memperlihatkan kemungkinan yang lebih tinggi untuk membeli produk itu lagi. Pelanggan yang tidak puas tersebut akan berusaha mengurangi ketidakpuasannya, karena dengan kodrat manusia untuk menciptakan keserasian, konsistensi, dan keselarasan di antara pendapat, pengetahuan dan nilai-nilai di dalam dirinya. Pelanggan yang tidak puas akan mengambil satu atau dua tindakan. Mereka mungkin akan mengurangi ketidakcocokannya dengan meninggalkan atau mengembalikan produk, atau mereka mungkin berusaha mengurangi ketidakcocokan dengan mencari informasi yang mungkin mengkonfirmasikannya produk tersebut sebagai bernilai tinggi.

Para pemasar haruslah menyadari terhadap kemungkinan-kemungkinan yang dilakukan pelanggan untuk mengatasi ketidakpuasan. Pelanggan memiliki pilihan antara melakukan tindakan atau tidak melakukan tindakan. Tindakan bersama tersebut mengeluh kepada perusahaan, mendatangi pengacara, mengeluh kepada kelompok-kelompok lain yang mungkin dapat mengurangi ketidakpuasan. Atau pembeli dapat menghentikan pembelian terhadap produk tersebut, yaitu memanfaatkan hak untuk keluar. Alternatif lain adalah pelanggan mungkin memilih menggunakan hak suara. Apapun yang dilakukannya, penjual kehilangan sesuatu akibat telah melakukan pekerjaan yang buruk dalam memuaskan pelanggan.

\section{Cara Meningkatkan Kepuasan Pelanggan}

Mempertahankan pelanggan yang sudah ada lebih sulit dibandingkan mencari pelanggan baru, karena mempertahankan pelanggan yang sudah ada meningkatkan rentensi pelanggan. Caranya adalah dengan defensive marketing, misalnya dengan melakukan efisiensi biaya, meningkatkan volume pembelian kembali, menerapkan strategi harga premium serta 
melakukan strategi promosi yang tepat. Sebaliknya, upaya mencari pelanggan baru merupakan offensive marketing, yaitu dengan cara meningkatkan pangsa pasar, meningkatkan reputasi atau citra produk melalui strategi merek, serta penerapan strategi price premium.

Strategi defensive marketing akan menghasilkan margin keuntungan yang tinggi, sementara strategi offensive marketing akan menghasilkan margin keuntungan relatif kecil, tetapi perusahaan akan menikmati peningkatan penjualan yang cukup besar. Gabungan dari dua strategi pemasaran ini akan menghasilkan profit yang cukup besar. Tujuan strategi kepuasan pelanggan adalah membuat agar pelanggan tidak mudah pindah ke pesaing.

Menurut Rangkuti (2003:55), strategi yang dapat dipadukan untuk meraih dan meningkatkan kepuasan pelanggan adalah:

1. Strategi relationship marketing. Dalam strategi ini transaksi antara pembeli dan penjual berlanjut setelah penjualan selesai. Dengan kata lain, perusahaan menjalin suatu kemitraan dengan pelanggan secara terus-menerus yang pada akhirnya akan menimbulkan kesetiaan pelanggan sehingga bisnis ulang. Agar relationship marketing dapat diimplementasikan, perlu dibentuk database pelanggan, yaitu daftar nama pelanggan yang dianggap perlu baik dalam jangka panjang. Informasi yang tersedia mengenai nama pelanggan, frekuensi, jumlah pembelian, diharapkan perusahaan dapat memuaskan pelanggannya secara lebih baik yang pada gilirannya dapat menumbuhkan loyalitas pelanggan. Tetapi, perlu diperhatikan bahwa dampak kepuasan perlanggan terhadap loyalitas pelanggan berbeda untuk setiap perusahaan. Pelanggan yang loyal belum tentu puas, tetapi pelanggan yang puas cenderung untuk menjadi pelanggan yang loyal.

2. Strategi unconditional serice guarantee. Strategi memberikan garansi secara mutlak dirancang untuk meringankan risiko atau kerugian di pihak pelanggan. Garansi tersebut menjanjikan kualitas prima dan kepuasan pelanggan yang optimal, sehingga dapat menciptakan loyalitas pelanggan yang tinggi. Caranya adalah dengan memberikan komitmen untuk memberikan kepuasan kepada para pelanggan, yang pada gilirannya akan menjadi sumber penyempurnaan mutu produk dan akan meningkatkan motivasi karyawan untuk mencapai tingkat kinerja yang lebih baik dari pada sebelumnya.

3. Strategi superior customer service. Strategi yang menawarkan pelayanan yang lebih baik dibandingkan dengan yang ditawarkan pesaing. Dana yang besar, sumber daya manusia yang andal, dan usaha yang diperlukan agar perusahaan dapat menciptakan pelayanan yang superior. Yang sering terjadi adalah perusahaan menawarkan customer service yang lebih tetapi memberi harga yang lebih tinggi pada produk-produknya. Tetapi biasanya mereka memperoleh manfaat yang lebih besar dari pelayanan yang lebih baik tersebut, yaitu tingkat pertumbuhan yang lebih cepat dan laba yang lebih besar.

4. Strategi penangan keluhan yang efektif. Ini adalah strategi menangani keluhan pelanggan dengan cepat dan tepat, di mana perusahan harus menunjukkan perhatian, keprihatinan, dan penyesalan atas kekecewaan pelanggan agar pelanggan tersebut dapat kembali menjadi pelanggan yang puas, dan kembali menggunakan produk perusahaan tersebut. Proses penanganan keluhan pelanggan yang efektif dimulai dari identifikasi dan penentuan sumber masalah menyebabkan pelanggan tidak puas dan mengeluh.

5. Strategi peningkatan kinerja perusahaan. Perusahaan menerapkan strategi yang dapat meningkatkan kualitas pelayanan secara berkesinabunan, memberikan pendidikan dan pelatihan komunikasi, salesmanship, dan public relation kepada pihak manajemen dan karyawan, memasukkan unsur kemampuan memuaskan pelanggan ke dalam sistem penilaian prestasi karyawan.

\section{Keputusan Pembelian}

Suatu keputusan dapat dibuat hanya jika ada beberapa alternatif yang dipilih. Apabila alternatif pilihan tidak ada maka tindakan yang dilakukan tanpa adanya pilihan tersebut tidak dapat dikatakan membuat keputusan. Menurut Kotler dan Armstrong (2008:181), keputusan 
pembelian konsumen adalah membeli merek yang paling disukai dari berbagai alternatif yang ada, tetapi dua faktor bisa berada antara niat pembelian dan keputusan pembelian. Faktor pertama adalah sikap orang lain dan faktor yang kedua adalah faktor situasional. Oleh karena itu, preferensi dan niat pembelian tidak selalu menghasilkan pembelian yang aktual.

Pengambilan keputusan merupakan suatu kegiatan individu yang secara langsung terlibat dalam mendapatkan dan mempergunakan barang yang ditawarkan. Menurut Setiadi, (2003:341), mendefinisikan suatu keputusan (decision) melibatkan pilihan diantara dua atau lebih alternatif tindakan atau perilaku. Keputusan selalu mensyaratkan pilihan diantara beberapa perilaku yang berbeda.

Berdasarkan uraian di atas dapat disimpulkan bahwa keputusan pembelian merupakan kegiatan pemecahan masalah yang dilakukan individu dalam pemilihan alternatif perilaku yang sesuai dari dua alternatif perilaku atau lebih dan dianggap sebagai tindakan yang paling tepat dalam membeli dengan terlebih dahulu melalui tahapan proses pengambilan keputusan.

Proses pengambilan keputusan merupakan perilaku yang harus dilakukan untuk dapat mencapai sasaran, dan dengan demikian dapat mèmecahkan masalahnya, dengan kata lain proses pemecahan suatu masalah yang diarahkan pada sasaran. Proses keputusan pembelian yang spesifik menurut Kotler dan Armstrong (2008:179) terdiri dari urutan kejadian berikut: pengenalan masalah kebutuhan, pencarian informasi, evaluasi alternatif, keputusan pembelian dan perilaku pasca pembelian. Secara rinci tahap-tahap ini dapat digambarkan sebagai berikut:

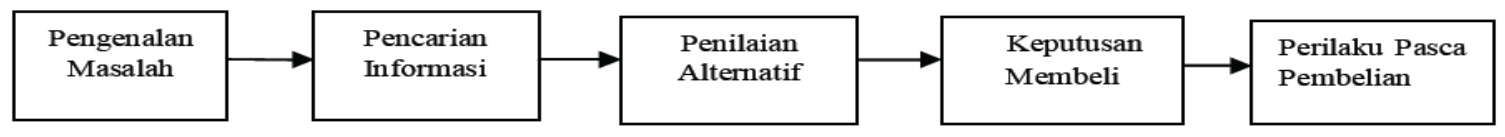

Keterangan :

\section{Gambar 5. Proses Pengambilan Keputusan Konsumen}

1. Pengenalan Kebutuhan. Proses pembelian oleh konsumen diawali sejak pembeli mengenali kebutuhan ataumasalah. Kebutuhan tersebut dapat ditimbulkan oleh rangsangan internal atau eksternal. Rangsangan internal, terjadi pada salah satu kebutuhan umum seseorang (seperti lapar dan haus) telah mencapai ambang batas tertentu dan mulai menjadi pendorong. Sedangkan rangsangan eksternal, salah satunya terjadi karena seseorang menonton iklan atau melihat produk baru milik tetangganya.

2. Pencarian Informasi. Setelah konsumen yang terangsang kebutuhannya, konsumen akan terdorong untuk mencari informasi yang lebih banyak. Orang lebih peka terhadap informasi produk. Selanjutnya, orang mulai aktif mencari informasi: bertanya kepada teman, mendatangi toko untuk mencari tahu atau membuka-buka internet untuk membandingkan spesifisikasi dan harga barang.

3. Evaluasi Alternatif. Evaluasi umunya mencerminkan keyakinan dan sikap yang mempengaruhi perilaku pembelian mereka. Keyakinan (belief) adalah gambaran pemikiran yang dianut seseorang tentang gambaran sesuatu. Keyakinan seseorang tentang produk atau merek mempengaruhi keputusan pembelian mereka. Yang tak kalah pentingnya dengan keyakinan adalah sikap. Sikap (attitude) adalah evaluasi, perasaan emosi, dan kecenderungan tindakan yang menguntungkan atau tidak menguntungkan dan bertahan lama pada sesorang pada objek atau gagasan tertentu (Kotler dan Keller, 2007).

4. Keputusan Pembelian. Dalam suatu kasus pembelian, konsumen bisa mengambil beberapa sub keputusan, meliputi merk, pemasok, jumlah, waktu pelaksanaan dan metode pembayaran. untuk produk-produk yang komplek akan membutuhkan pertimbangan yang pajang sebelum memutuskan pembelian, sedangkan untuk produkproduk yang sederhana seperti kebutuhan sehari-hari konsumen cenderung lebih mudah 
memutuskan untuk pembelian. Pada fase ini perusahaan harus sebisa mungkin memudahkan konsumen untuk dapat mengakuisisi produk yang di inginkan, seperti kemudahan memperoleh produk kemudahan untuk melakukan pembayaran, kemudahan untuk dapat konsultasi lebih lanjut. Implikasi strategi pemasaran: Perusahaan dapat mempercepat atau merangsang konsumen dengan memberikan promo-promo menarik agar konsumen segera mengakuisisi pembeliannya. Seperti pemberian potongan harga, pemberian jumlah tertenu, program bonus, program bundling dsb, bahkan perusahaan juga dapat memfasilitasi bagi konsumen yang ingin melakukan pembelian dengan metode kredit.

5. Perilaku Pasca Pembelian. Setelah pembelian dilakukan, konsumen akan selalu siaga terhadap informasi yang mendukung keputusannya. Konsumen akan membandingkan produk yang telah ia beli, dengan produk lain. Hal ini dikarenakan konsumen mengalami ketidakcocokan dengan fasilitas-fasilitas tertentu pada barang yang telah ia beli, atau mendengar keunggulan tentang merek lain. Pada fase ini anda akan memberikan respon atau feedback atas produk yang telah dibeli, apakah anda puas atau tidak puas. Banyak respon yang terjadi seperti anda bisa memberikan rèkomendasi ke kerabat atau keluarga anda, atau bahkan bila anda sangat puas atas produk pilihan anda maka anda menjadi loyal terhadap produk ataupun merek produk tersebut. Implikasi strategi pemasaran: Perusahaan dapat merespon dengan memberikan pelayanan purna jual, memberikan instruksi atas produk yang dibelinya, atau memberikan garansi yang yang sesuai atas produknya.

\section{N. Tipe Keputusan Pembelian}

Keputusan pembelian merupakan kontinum dan memiliki dua dimensi. Dimensi pertama adalah degree, menunjukkan keterlibatan konsumen di dalam keputusan membeli yaitu dari high involvement purchase decision ke low involvement purchase decision. Dimensi kedua adalah content, menunjukkan jumlah informasi yang dibutuhkan oleh konsumen untuk dapat membuat keputusan pembelian yaitu dari decision making (mencari informasi dan mempertimbangkan berbagai alternatif merk) ke habit (sedikit membutuhkan informasi dan hanya mempertimbangkan satu merk saja). Pembuatan keputusan pembelian dapat bergerak dari pembuatan keputusan pembelian dengan keterklibatan tinggi (high involvement purchase decision) ke pembuatan keputusan pembelian dengan keterlibatan rendah (low involvement purchase decision). Konsumen akan lebih terlibat dengan suatu produk ketika produk yang akan dibeli memiliki kriteria sebagai berikut.
a. Penting bagi konsumen
b. Memiliki keterlibatan emosional
c. Secara kontinyu menarik bagi konsumen
d. Mengakibatkan resiko keuangan
e. Merupakan identitas yang menciptakan image khusus bagi konsumen

Dengan demikian, semakin penting dan beresiko suatu produk yang akan dibeli, konsumen semakin mempertimbangkan berbagai merk dan mencari berbagai informasi yang dibutuhkan.

a. Complex decision making. Complex decision making bisa terjadi, ketika konsumen melakukan pembelian produk yang membutuhkan berbagai pertimbangan sehubungan dengan pentingnya produk dan tingginya resiko bagi indvidu konsumen. Pada umumnya, konsumen akan mempertimbangkan berbagai merk dan mencari berbagai informasi yang dibutuhkan sebelum membeli rumah atau mobil, konsumen akan mempertimbangkan secara selektif setiap detai perbedaan dari masing-masing produk. Informasi ini penting bagi konsumen, supaya tidak terjadi post purchase dissonance (ketidaknyamanan setelah pembelian). 
b. Limited decision making. Limited decision making terjadi ketika konsumen melakukan keputusan untuk membeli suatu produk yang membutuhkan pertimbangan merk dan informasi, yang secara kontinyu menarik bagi konsumen atau konsumen sering mengkonsumsi atau menggunakan produk tersebut. Proses pembuatan keputusan terbatas ini membutuhkan lebih sedikit informasi daripada complex decision making. Berdasar teorinya, pembelian cereal atau makanan ringan termasuk dalam limited decision making. Namun bagi konsumen yang sedang melakukan diet kalori atau konsumen yang berwawasan green product, atau natural product, mereka akan melakukan pencarian informasi yang lebih banyak untuk memutuskan pembelian produk cereal atau makanan ringan, daripada konsumen pada umumnya, sehingga pembuatan keputusannya termasuk complex.

c. Brand loyalty. Brand loyalty menunjukkan sikap loyal terhadap merk tertentu dan berdampak pada pembelian secara konsisten sepanjang waktu. Konsumen yang loyal terhadap merk tertentu akan melakukan pembelian merk tersebut dalam jangka panjang, dan membutuhkan informasi yang relatif sedikit, karena sudah menjadi kebiasaannya untuk membeli produk dengan merk tersebut. Loyalitas konsumen terhadap merk tertentu ini disebabkan oleh rasa puas atau rasa keinginan dan kebutuhan yang terpenuhi terhadap merk tersebut secara berulang-ulang sehingga menjadi kebiasaan.

d. Inertia. Ketika konsumen menggunakan hirarki low involvement, konsumen membentuk keyakinan terhadap produk secara pasif dan membuat keputusan hanya dengan memproses sedikit informasi dan selanjutnya mengevaluasi merk setelah pembelian. Jenis produk inertia antara lain garam dapur, gula, deterjen, dll. Konsumen tidak perlu pikir panjang untuk membeli garam dapur berdasarkan pengalamannya di masa lalu terhadap merk tertentu, atau merk lain yang tersedia di toko. Proses ini kadang disebut dengan spurious loyalty, karena seakan-akan konsumen loyal terhadap merk garam tersebut, namun ketika merk garam yang dimaksud tidak tersedia, konsumen akan dengan cepat beralih merk tanpa pikir panjang lagi, konsumen membeli produk itu bukan karena loyalitas pada merek tetapi keinginan untuk menghindari proses keputusan yang berbelit.

e. Impulse Purchasing. Tipe keputusan ini dikenal dengan keputusan pembelian tiba-tiba, dikatakan demikian karena konsumen tidak membutuhkan banyak pertimbangan untuk melakukan pembelian. Proses keputusan dapat dilakukan dengan cepat, tanpa harus menunggu pencarian informasi dan judgement tertentu untuk memilih produk. Bagi konsumen merek itu sendiri sudah cukup dipergunakan sebagai dasar untuk membandingkan produk. Satu hal lagi yang perlu diingat tipe keputusan ini adalah bahwa konsumen realtif tidak menghadapi switching cost (biaya yang timbul atas peralihan keproduk lain) yang tinggi.

\section{O. Kerangka Pemikiran Teoritis}

Berdasarkan telaah pustaka dan hipotesis yang dikembangkan diatas maka sebuah model untuk penelitian ini dapat dikembangkan seperti pada gambar 6. Model tersebut terdiri dari variabel persepsi kualitas, harga, reputasi perusahaan, kepuasan pelanggan dan Pengambilan Keputusan Jasa Penerbangan.
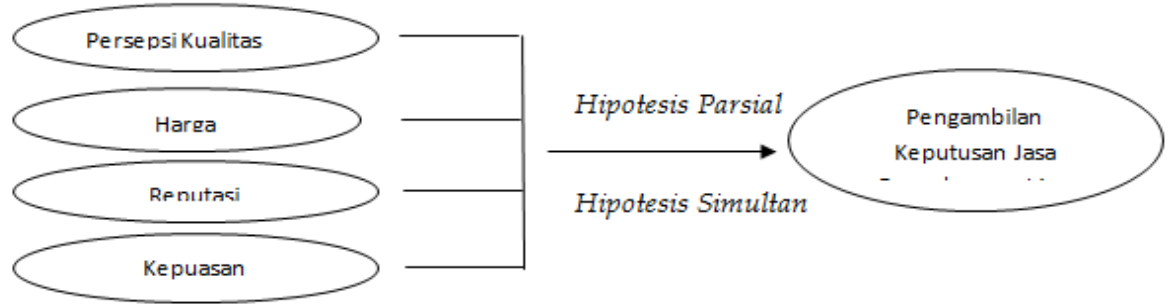

Gambar 6. Kerangka Pemikiran Teoritis

Sumber : Dikembangkan untuk penelitian ini 


\section{METODE PENELITIAN}

\section{A. Populasi dan Sampel}

Populasi pada penelitian ini adalah seluruh pelanggan jasa penerbangan PT. Lion Air . Sampel penelitian ini sebagian dari anggota populasi. Berdasarkan tingkat keyakinan 95\% (a $\left.=5 \%, Z^{1} / 2 \alpha=1,96\right)$, kesalahan maksimum $(\varepsilon)=0,1$ dan standar deviasi $(\sigma)=0,5$ maka rumus penentuan sampel (Supranto, 2001: 113):

$$
\begin{aligned}
n & =\left(\frac{z_{\alpha / 2}{ }^{2} \times \sigma}{\varepsilon}\right)^{2} \\
& =\left(\frac{1,96 \times 0,5}{0,1}\right)^{2} \\
& =96,04 \text { orang }
\end{aligned}
$$

Dalam penelitian ini, maka jumlah sampel yang dibutuhkan $(n)=96,04$ dibulatkan menjadi

96 orang. Teknik penentuan sampel dilakukan secara purposive sampling..

\section{B. Operasionalisasi Variabel}

\begin{tabular}{|c|c|c|c|}
\hline Variabel & Definisi Operasional & Indikator & Pengukuran \\
\hline $\begin{array}{l}\text { Persepsi } \\
\text { Kualitas }\end{array}$ & $\begin{array}{l}\text { Persepsi pelanggan terhadap } \\
\text { keseluruhan kualitas atau } \\
\text { keunggulan suatu produk } \\
\text { atau jasa layanan berkaitan } \\
\text { dengan apa yang diharapkan } \\
\text { oleh pelanggan }\end{array}$ & $\begin{array}{l}\text { Keandalan } \\
\text { Ketanggapan } \\
\text { Keyakinan } \\
\text { Empati } \\
\text { Berwujud }\end{array}$ & $\begin{array}{l}\text { Diukur dengan } \\
\text { skala setuju - } \\
\text { tidak setuju, } \\
\text { range poin } \\
\text { penilaian } 1-5\end{array}$ \\
\hline Harga & $\begin{array}{l}\text { Suatu pengorbanan yang di } \\
\text { persepsikan oleh konsumen } \\
\text { sebagai biaya untuk } \\
\text { memperoleh sejumlah barang } \\
\text { atau jasa yang } \\
\text { dibutuhkan }\end{array}$ & $\begin{array}{l}\text { Perkiraan harga } \\
\text { Kesesuaian } \\
\text { Pengorbanan } \\
\text { Kewajaran harga }\end{array}$ & $\begin{array}{l}\text { Diukur dengan } \\
\text { skala setuju - } \\
\text { tidak setuju, } \\
\text { range poin } \\
\text { penilaian } 1-5\end{array}$ \\
\hline $\begin{array}{l}\text { Reputasi } \\
\text { Perusahaan }\end{array}$ & $\begin{array}{l}\text { Kepercayaan konsumen atas } \\
\text { nama baik dari penyedia jasa }\end{array}$ & $\begin{array}{l}\text { Pengalaman } \\
\text { perusahaan } \\
\text { Kompetensi } \\
\text { perusahaan } \\
\text { Keunggulan } \\
\text { perusahaan }\end{array}$ & $\begin{array}{l}\text { Diukur dengan } \\
\text { skala setuju - } \\
\text { tidak setuju, } \\
\text { range poin } \\
\text { penilaian } 1 \text { - } 5\end{array}$ \\
\hline $\begin{array}{l}\text { Kepuasan } \\
\text { Pelanggan }\end{array}$ & $\begin{array}{l}\text { Tingkat kepuasan konsumen } \\
\text { terhadap pengalaman } \\
\text { melakukan konsumsi suatu } \\
\text { produk atau jasa yang } \\
\text { diperoleh dari kemampuan } \\
\text { penyedia untuk memenuhi } \\
\text { harapan dan kebutuhan } \\
\text { pelanggan }\end{array}$ & $\begin{array}{l}\text { Kesesuaian harapan } \\
\text { Persepsi kinerja } \\
\text { Penilaian pelanggan }\end{array}$ & $\begin{array}{l}\text { Diukur dengan } \\
\text { skala setuju - } \\
\text { tidak setuju, } \\
\text { range poin } \\
\text { penilaian } 1 \text { - } 5\end{array}$ \\
\hline $\begin{array}{l}\text { Keputusan } \\
\text { Pembelian }\end{array}$ & $\begin{array}{l}\text { Tahapan-tahapan yang } \\
\text { dilakukan konsumen sebelum } \\
\text { melakukan pembelian } \\
\text { terhadap suatu produk. }\end{array}$ & $\begin{array}{l}\text { Pengenalan Kebutuhan, } \\
\text { Pencarian Informasi, } \\
\text { Evaluasi Alternatif, } \\
\text { Keputusan Pembelian, } \\
\text { Perilaku } \\
\text { Pascapembelian. }\end{array}$ & $\begin{array}{l}\text { Diukur dengan } \\
\text { skala setuju - } \\
\text { tidak setuju, } \\
\text { range poin } \\
\text { penilaian } 1 \text { - } 5\end{array}$ \\
\hline
\end{tabular}

Defenisi operasionalisasi variabel yang diteliti dapat dilihat pada tabel berikut:

Tabel 1. Definisi Operasional Variabel 
Volume 17 Nomor 2

\begin{tabular}{|l|l|l|l|}
\hline Variabel & Definisi Operasional & Indikator & Pengukuran \\
\hline & & & \\
\hline
\end{tabular}

Sumber : Dikembangkan untuk penelitian ini

\section{Teknik Pengumpulan Data}

Pada penelitian ini digunakan metode pengumpulan data primer melalui metode survei yang terdiri dari wawancara dan kuisioner sebagai berikut :

1. Wawancara. Wawancara merupakan teknik pengumpulan data dalam metode survei yang menggunakan pertanyaan secara lisan kepada subyek penelitian.

2. Koeisioner. Koesioner merupakan metode pengumpulan data yang diperoleh dari jawaban yang diberikan responden berdasarkan daftar pertanyaan yang telah disusun sebelumnya. Pada penelitian ini digunakan kuisioner dengan skala Likert dimana pernyataan-pernyataan dalam kuisioner dibuat dengan nilai 1 sampai dengan 5 untuk mewakili pendapat responden seperti sangat tidak puas sampai dengan sangat puas.

\section{Metode analisis}

\section{a. Uji Validitas dan Reliabilitas Instrumen}

Uji validitas berguna untuk mengetahui ketepatan hasil kuesioner. Pengujian validitas tiap butir digunakan analisis item, yaitu mengkorelasikan skor tiap butir dengan skor total, yang merupakan jumlah tiap skor butir. Teknik korelasi untuk menentukan validitas item ini sampai sekarang merupakan teknik yang paling banyak digunakan. Selanjutnya dalam memberikan interprestasi terhadap koefisien korelasi, dimana item yang mempunyai korelasi positif dengan kriteria (skor total) serta korelasi yang tinggi, menunjukkan bahwa item tersebut mempunyai validitas yang tinggi pula.

Menurut Sugiyono (2005:114), "jumlah anggota sampel digunakan sekitar 30 orang". Biasanya, syarat minimum yang dianggap memenuhi syarat adalah jika nilai $r=0,30$ jadi korelasi antara butir dengan skor total kurang dari 0,30, maka butir dalam instrumen tersebut dinyatakan tidak valid. Untuk menghitung koefisien korelasi digunakan "korelasi product moment" dengan rumus:

$$
r_{x y}=\frac{n \sum X Y-\left(\sum X\right)\left(\sum Y\right)}{\sqrt{\left\{n \sum X^{2}-\left(\sum X\right)^{2}\right\}}\left\{n \sum Y^{2}-\left(\sum Y\right)^{2}\right\}}
$$

Keterangan: $\mathrm{X}=$ skor tiap butir, $\mathrm{Y}=$ skor total butir dan $\mathrm{n}=$ jumlah responden

Uji reliabilitas berguna untuk mengetahui apakah hasil kuesioner dapat dipercaya atau tidak. Pengujian reliabilitas instrumen dapat dilakukan secara internal yang diuji dengan menganalisis konsistensi butir-butir yang ada pada instrumen dengan teknik tertentu.

Menurut Sugiyono (2005:122), "pengujian reliabilitas dengan internal consistency, dilakukan dengan cara mencoba instrumen sekali saja, kemudian yang data diperoleh dianalisis dengan teknik tertentu. Hasil analisis dapat digunakan untuk memprediksi reliabilitas instrumen. Pengujian reliabilitas instrumen dilakukan dengan teknik belah dua dari Spearmen Brown dengan rumus:

$$
r i=\frac{2 r b}{1+r b}
$$

Keterangan : $r_{i}=$ reliabilitas internal seluruh instrumen

$\mathrm{rb}=$ korelasi product moment antara belahan pertama dan kedua.

Perhitungan reliabilitas pada penelitian ini menggunakan analisis yang dikembangkan oleh Alpha Cronbach. Pada uji ini dinilai reliabel jika lebih besar dari 0,5 di mana kriteria sebagai berikut : $\alpha \geq 0,50$ artinya instrumen reliabel dan apabila $\quad \alpha<0,50$ artinya instrumen tidak reliabel. 


\section{b. Regresi Berganda}

Teknik analisis data regresi linier berganda (multiple regression analysis) (Sugiyono, 2005). bertujuan untuk mencari pengaruh variabel bebas terhadap variabel terikatnya. Maka persamaan regresi linier berganda dapat dirumuskan sebagai berikut :

$$
Y=\beta_{0}+\beta_{1} X 1+\beta_{2} X 2+\beta_{3} X 3+\beta_{0} X 4+\text { ei }
$$

Keterangan :

$\mathrm{Y}=$ Variabel Terikat, $\mathrm{X} 1, \mathrm{X} 2$ dan $\mathrm{X} 3=$ Variabel Bebas, ei $=$ Kesalahan dalam estimasi, $\mathrm{bo}=$ Konstanta, b1,b2,b3, b4 = Koefisien Regresi.

Persamaan regresi linier berganda tersebut diaplikasikan untuk melihat pengaruh persepsi kualitas, harga, reputasi perusahaan dan kepuasan pelanggan terhadap pengambilan keputusan pembelian jasa penerbangan yang diaplikasikan, dengan rumus:

$P K P=\beta_{0}+\beta_{1} P K+\beta_{2} H+\beta_{3} R P+\beta_{4} \mathrm{KP}+\varepsilon$

Keterangan : PKP = Pengambilan Keputusan Pembelian, $\mathrm{PK}=$ Persepsi Kualitas, $\mathrm{H}=$ Harga, $\mathrm{RP}=$ Reputasi Perusahaan, $\mathrm{KP}=$ Kepuasan Pelanggan, $\beta_{0}=$ Konstanta, $\varepsilon=$ Tingkat kesalahan estimasi dan $\beta_{1} \beta_{2} \beta_{3} \beta_{4}=$ Koefisien regresi

Untuk membuktikan apakah hipotesis digunakan uji $\mathrm{F}$ dan $\mathrm{t}$.

\section{c. Uji F}

1. $\mathrm{H}_{0}: \beta \mathrm{i}=0$, artinya persepsi kualitas, harga, reputasi perusahaan dan kepuasan pelanggan tidak berpengaruh signifikan secara simultan terhadap pengambilan keputusan pembelian jasa penerbangan Lion Air.

$\mathrm{H}_{1}: \beta \mathrm{i} \neq 0$, artinya persepsi kualitas, harga, reputasi perusahaan dan kepuasan pelanggan berpengaruh signifikan secara simultan terhadap pengambilan keputusan pembelian jasa penerbangan Lion Air.

2. Tingkat Keyakinan $95 \%$ dengan Jumlah sampel $=96$ responden

Level of significan $(\alpha)=5 \%$

3. Uji statistik F:

$$
F=\frac{R^{2} /[k-1]}{\left[1-R^{2}\right] /(n-k)}
$$

Keterangan: $\mathrm{k}=$ Jumlah variabel, $\mathrm{R}^{2}=$ koefisien determinan, $\mathrm{n}=$ Jumlah sampel

4. Kriteria pengujian: $\mathrm{H}_{0}$ diterima jika $\mathrm{F}_{\text {hitung }} \leq \mathrm{F}_{\text {tabel }}$ atau $\mathrm{H}_{1}$ diterima jika $\mathrm{F}_{\text {hitung }}>\mathrm{F}$ tabel

5.. Kesimpulan : Dengan membandingkan langkah 3 dan 4 untuk menerima atau menolak hipotesis.

\section{d. Uji t}

1. $\mathrm{H}_{0}: \beta \mathrm{i}=0$, artinya persepsi kualitas, harga, reputasi perusahaan dan kepuasan pelanggan tidak berpengaruh signifikan secara parsial terhadap pengambilan keputusan pembelian jasa penerbangan Lion Air.

$\mathrm{H}_{1}: \beta \mathrm{i} \neq 0$, artinya persepsi kualitas, harga, reputasi perusahaan dan kepuasan pelanggan berpengaruh signifikan secara parsial terhadap pengambilan keputusan pembelian jasa penerbangan Lion Air.

1. Tingkat Keyakinan $95 \%$ dan Jumlah sampel $=96$ responden

3. Uji statistik $\mathrm{t}$ :

$$
t=\frac{\beta s-\beta}{S . E[\beta s]}
$$

Keterangan: $t=t_{\text {hitung, }}, \beta_{S}=$ koefisien regresi, S.E $[\beta i]=$ Standar error koefisien regresi

4. Kriteria pengujian:

$\mathrm{H}_{0}$ diterima jika $-\mathrm{t}_{\alpha / 2}: \mathrm{dk} \leq \mathrm{t}_{\text {hitung }} \leq \mathrm{t}_{\alpha / 2}: \mathrm{dk}$

$\mathrm{H}_{1}$ diterima jika $\mathrm{t}_{\text {hitung }}>\mathrm{t}_{\alpha / 2}$ : $\mathrm{dk}$ atau $\mathrm{t}_{\text {hitung }}<-\mathrm{t}_{\alpha / 2}: \mathrm{dk}$ 
5.. Kesimpulan : Dengan membandingkan langkah 3 dan 4 untuk menerima atau menolak hipotesis.

\section{HASIL DAN PEMBAHASAN}

\section{A. Hasil Penelitian}

Pengaruh persepsi kualitas, harga, reputasi perusahaan dan kepuasan pelanggan terhadap pengambilan keputusan pembelian jasa penerbangan.

Berdasarkan teknik analisis yang digunakan dengan persamaan Regresi Berganda untuk melihat pengaruh variabel persepsi kualitas, harga, reputasi perusahaan dan kepuasan pelanggan terhadap pengambilan keputusan pembelian jasa penerbangan menunjukkan hasil sebagai berikut :

Tabel 2. Coefficientsa variabel

\begin{tabular}{|c|c|c|c|c|c|c|}
\hline & & \multicolumn{2}{|c|}{$\begin{array}{l}\text { Unstandardized } \\
\text { Coefficients }\end{array}$} & \multirow{2}{*}{$\begin{array}{l}\text { Standardized } \\
\text { Coefficients } \\
\text { Beta }\end{array}$} & \multirow[b]{2}{*}{$\mathbf{t}$} & \multirow[b]{2}{*}{ Sig. } \\
\hline \multicolumn{2}{|c|}{ Model } & B & Std. Error & & & \\
\hline 1 & $\begin{array}{l}\text { (Constant) } \\
\text { PK } \\
\text { H } \\
\text { RP } \\
\text { KP }\end{array}$ & $\begin{array}{l}12.034 \\
.624 \\
.873 \\
.505 \\
.705\end{array}$ & $\begin{array}{l}1.369 \\
.134 \\
.238 \\
.147 \\
.047\end{array}$ & $\begin{array}{l}.018 \\
.608 \\
.012 \\
.700\end{array}$ & $\begin{array}{l}8.790 \\
4.656 \\
3.668 \\
3.435 \\
14.943\end{array}$ & $\begin{array}{l}.000 \\
.000 \\
.000 \\
.000 \\
.000\end{array}$ \\
\hline
\end{tabular}

Dependent Variable pengambilan keputusan pembelian jasa penerbangan, Independent Variable.

PK(Persepsi Kualitas), H(Harga ) RP(Reputasi Perusahaan ) dan Kepuasan Pelanggan. Berdasarkan tabel di atas, menunjukkan persamaan regresi : PKP $=12,034+.624$ PK 0,873H + 0,505RP + .705KP. Persamaan tersebut menunjukkan bahwa variabel persepsi kualitas, harga, reputasi perusahaan dan kepuasan 5 pelanggan mempunyai pengaruh yang positif terhadap pengambilan keputusan pembelian jasa penerbangan pada PT. Vina Tour \& Travel Medan. Dari keempat variabel yang lebih berpengaruh terhadap terhadap pengambilan keputusan pembelian jasa penerbangan yaitu variabel harga dan kepuasan pelanggan,

Tabel 3. Koefisien Korelasi dan Determinasi

\begin{tabular}{|l|l|l|l|l|}
\hline Model & R & R Square & Adjusted R Square & $\begin{array}{l}\text { Std. Error of the } \\
\text { Estimate }\end{array}$ \\
\hline 1 & $.843^{\mathrm{a}}$ & .710649 & .710629 & 1.829 \\
\hline
\end{tabular}

Dependent Variable pengambilan keputusan pembelian jasa penerbangan, Independent Variable. PK(Persepsi Kualitas), H(Harga ) RP(Reputasi Perusahaan ) dan Kepuasan Pelanggan.

Berdasarkan tabel di atas menunjukkan koefisien korelasi variabel persepsi kualitas, harga, reputasi perusahaan dan kepuasan pelanggan terhadap pengambilan keputusan pembelian jasa penerbangan mempunyai hubungan yang sangat kuat dengan nilai $r=0,843$. Koefisien determinasinya sebesar $\mathrm{r}^{2}=0,710629$, artinya variabel variabel persepsi kualitas, harga, reputasi perusahaan dan kepuasan pelanggan mampu menjelaskan $71,06 \%$ terhadap pengambilan keputusan pembelian jasa penerbangan, sedangkan $28,94 \%$ dipengaruhi oleh faktor-faktor lain.

Tabel 4. Nilai F. hitung 
Volume 17 Nomor 2

\begin{tabular}{|l|l|l|l|l|l|l|}
\hline \multicolumn{2}{|l|}{ Model } & Sum of Squares & df & Mean Square & F & Sig. \\
\hline 1 & Regression & 190.673 & 1 & 190.673 & 105.067 & $.000^{\mathrm{a}}$ \\
& Residual & 325.483 & 94 & 3.463 & & \\
& Total & 516.156 & 95 & & & \\
\hline
\end{tabular}

Dependent Variable pengambilan keputusan pembelian jasa penerbangan, Independent Variable.

PK(Persepsi Kualitas), H(Harga ) RP(Reputasi Perusahaan) dan Kepuasan Pelanggan

Berdasarkan tabel 3 dan 4 menunjukkan nilai $t$ hitung keempat variabel $>\mathrm{t}$ tabel artinya secara parsial keempat variabel bebas mempunyai pengaruh yang signifikan terhadap pengambilan keputusan pembelian jasa penerbangan. Berdasarkan tabel 5.18 menunjukkan bahwa F hitung (Variabel persepsi kualitas, harga, reputasi perusahaan dan kepuasan pelanggan) $>\mathrm{F}$ tabel, artinya secara simultan variabel tersebut mempunyai pengaruh yang signifikan terhadap pengambilan keputusan pembelian jasa penerbangan pada PT. Vina Tour \& Travel Medan.

\section{B. Pembahasan}

Persamaan regresi berganda dari hasil penelitian ini : $\mathrm{PKP}=12,034+.624 \mathrm{PK} 0,873 \mathrm{H}+$ $0,505 \mathrm{RP}+.705 \mathrm{KP}$. Persamaan tersebut menunjukkan bahwa variabel persepsi kualitas, harga, reputasi perusahaan dan kepuasan pelanggan mempunyai pengaruh yang positif terhadap pengambilan keputusan pembelian jasa penerbangan. Dari keempat variabel yang lebih berpengaruh terhadap terhadap pengambilan keputusan pembelian jasa penerbangan yaitu variabel harga dan kepuasan pelanggan.

Berdasarkan hasil regresi berganda menunjukkan bahwa : Persepsi kualitas berpengaruh positif terhadap keputusan pembelian. Hal ini sejalan dengan pendapat Vincent $(1997$; 35) yang menyatakan bahwa faktor yang mempengaruhi persepsi kualitas yaitu : 1 . Pengalaman masa lalu (terdahulu) dapat mempengaruhi seseorang karena manusia biasanya akan menarik kesimpulan yang sama dengan apa yang la lihat, dengar, dan rasakan. 2 . Keinginan dapat mempengaruhi persepsi seseorang dalam hal membuat keputusan. Manusia cenderung menolak tawaran yang tidak sesuai dengan apa yang ia harapkan. 3. Pengalaman dari teman-teman, dimana mereka akan menceritakan pengalaman yang telah dialaminya. Hal ini berarti kualitas pelayanan yang diberikan PT. Vina Tour \& Travel Medan menunjukkan nilai yang positif. Lima dimensi kualitas jasa ( Keandalan, Ketanggapan, Keyakinan, Empati dan Berwujud) (Parasuraman, Zeithaml, dan Berry, 1988; Zeithaml et al, 1996) yang dipergunakan untuk memahami harapan dan persepsi konsumen terhadap kualitas jasa pada PT. Vina Tour \& Travel Medan sudah menjadi keharusan yang dilakukan untuk melayani pelanggannya.

Berdasarkan hasil regresi berganda menunjukkan bahwa : harga berpengaruh positif terhadap keputusan pembelian. Hal ini sejalan dengan pendapat Stedman (2000) bahwa harga merupakan salah satu faktor penting yang dapat mempengaruhi perilaku konsumen dalam pembelian merek, karena suatu barang atau jasa pastilah mempunyai nilai. Sedangkan nilai itu sendiri didasarkan dari harga, yang merupakan tolak ukur dari barang maupun jasa yang bersangkutan. Kennedy (1994) mengemukakan bahwa penjualan produk berkualitas tinggi kemungkinan dapat ditandai berdasarkan harga yang tinggi pula. Konsumen seringkali menggunakan harga sebagai petunjuk ekstrinsik atau indikator dari kualitas ataupun manfaat suatu produk. Hasil dari beberapa penelitian mengemukakan bahwa harga yang tinggi dari suatu merek seringkali dipersepsikan memiliki kualitas yang tinggi dan tidak peka terhadap persaingan potongan harga seperti merek-merek dengan harga yang rendah (Yoo, Donthu, dan Lee, 2000). Harga yang tinggi dapat menimbulkan persepsi kualitas produk atau jasa 
yang tinggi pula dari suatu merek (Monroe, 1973 dalam Ward, Chitty, and Achard, 2005; Dodds, Grewal, dan Monroe, 1991). Dalam penelitiannya, Ward, Chitty, and Achard (2005) mengukur persepsi harga dari konsumen dengan perkiraan besarnya harga yang bersedia dibayar oleh mereka untuk tiap merek terlibat. Teknik tersebut juga digunakan oleh AlSabbahy, Ekinci, dan Riley (2004) menilai persepsi responden terhadap kewajaran harga yang harus dibayar beradasarkan internal feeling dan pengetahuan mereka atas harga dari penyedia jasa lainnya pada bidang yang sama.

Berdasarkan hasil regresi berganda menunjukkan bahwa: reputasi perusahaan berpengaruh positif terhadap keputusan pembelian. Hal ini sejalan dengan pendapat Zeithaml (1988) bahwa kualitas yang dirasakan (perceived quality) dari suatu produk atau jasa erat hubungannya dengan reputasi yang diasosiasikan dengan nama merek. Reputasi perusahaan sangat penting dari sudut pandang pelanggan untuk memberikan gambaran terhadap kualitas produk atau jasa yang dihasilkan (Brown dan Dacin, 1997). Herbig, Milewicz dan Golden (1994) menyatakan bahwa reputasi perusahaan dapat dilihat dari kompetensi perusahaan tersebut dan keunggulan dibandingkan dengan kompetitornya. Lebih jauh lagi Moorman dan Minner (1997) menyatakan bahwa keahlian perusahaan tercermin dalam pengetahuan dan pengalaman perusahaan tersebut dalam industri yang dimasukinya.

Berdasarkan hasil regresi berganda menunjukkan bahwa: kepuasan pelanggan berpengaruh positif terhadap keputusan pembelian. Hal ini sejalan dengan pendapat Woodside $(1989,6)$ dkk, kepuasan langganan serta keseluruhan dengan pelayanan merupakan suatu fungsi dari kualitas pelayanan seluruhnya dan keseluruhan kepuasan pelayanan dipengaruhi secara terpisah baik oleh kualitas pelayanan juga oleh kepuasan hidup. Dengan kepuasan pelanggan atas pelayanan secara keseluruhan, yang merupakan fungsi dari kualitas pelayanan akan membuat pelanggan benar-benar merasa puas dan pelanggan yang puas akan memunculkan keinginan untuk ferus menjalin hubungan kemitraan (minat untuk membeli ulang). Keinginan tersebut akan muncul apabila terjadi persamaan persepsi antara pelanggan dengan pihak manajemen tentang berbagai faktor yang mempengaruhi kepuasan. Kepuasan pelanggan penting bagi para pemasar karena merupakan determinan dari pembelian ulang (Bearden dan Teel, 1983 dalam Woodside, Frey, dan Daly, 1989). Terdapat hubungan positif secara langsung antara kepuasan pelanggan dengan minat beli ulang yang didukung oleh hasil-hasil penelitian terhadap berbagai kategori produk dan jasa (Anderson dan Sullivan, 1993; Bolton, 1998; Cronin dan Taylor, 1992; Fornell, 1992; Oliver, 1980; Patterson dan Spreng, 1997; Rust dan Zahorik, 1993; Selnes, 1998; Swan dan Trawick, 1981; Taylor dan Baker, 1994; Woodside et al, 1989 dalam Hellier, Geursen, Carr, dan Rickard, 2003). Dengan adanya kepuasan dari pelanggan, maka pelanggan akan memiliki minat untuk menggunakan kembali jasa dari provider yang sama (Hellier, Geursen, Carr, dan Rickard, 2002; Cronin dan Taylor, 1992). Hasil-hasil penelitian tersebut mengemukakan bahwa kepuasan pelanggan secara keseluruhan pada layanan jasa berasosiasi kuat terhadap perilaku konsumen untuk melakukan keputusan pembelian.

\section{KESIMPULAN}

Berdasarkan hasil penelitian dan pembahasan terdapat beberapa kesimpulan :

1. Berdasarkan analisis induktif menunjukkan hasil persamaan regresi : PKP $=12,034+$ $.624 \mathrm{PK} 0,873 \mathrm{H}+0,505 \mathrm{RP}+.705 \mathrm{KP}$. Persamaan tersebut menunjukkan bahwa variabel persepsi kualitas, harga, reputasi perusahaan dan kepuasan pelanggan mempunyai pengaruh yang positif terhadap pengambilan keputusan pembelian jasa penerbangan. Dari keempat variabel yang lebih berpengaruh terhadap terhadap pengambilan keputusan pembelian jasa penerbangan yaitu variabel harga dan kepuasan pelanggan.

2. Koefisien korelasi variabel persepsi kualitas, harga, reputasi perusahaan dan kepuasan pelanggan terhadap pengambilan keputusan pembelian jasa penerbangan mempunyai hubungan yang sangat kuat dengan nilai $r=0,843$. Koefisien determinasinya sebesar $r^{2}=$ 
0,710629, artinya variabel variabel persepsi kualitas, harga, reputasi perusahaan dan kepuasan pelanggan mampu menjelaskan $71,06 \%$ terhadap pengambilan keputusan pembelian jasa penerbangan, sedangkan $28,94 \%$ dipengaruhi oleh faktor-faktor lain.

3. Berdasarkan Uji $t$, menunjukkan nilai $t$ hitung keempat variabel $>t$ tabel artinya secara parsial keempat variabel bebas mempunyai pengaruh yang signifikan terhadap pengambilan keputusan pembelian jasa penerbangan. Berdasarkan tabel 5.18 menunjukkan bahwa F hitung (Variabel persepsi kualitas, harga, reputasi perusahaan dan kepuasan pelanggan) $>\mathrm{F}$ tabel, artinya secara simultan variabel tersebut mempunyai pengaruh yang signifikan terhadap pengambilan keputusan pembelian jasa penerbangan.

\section{DAFTAR PUSTAKA}

Aaker, David A. (1997), Should You Take Your Brand to Where the action is, Harvard Business Review, Vol. 75, Sept/Oct, p.135-143.

Anderson, Eugene W., Claes Fornell, dan Donald R. Lehmann (1994), “Customer Satisfaction, Market Share, and Profitabiliy : Finding from Sweden", Journal of Marketing, Vol. 58, p.53-66.

Brown, Tom J. and Dacin, Peter A (1997), "The Company and the Product: Corporate Associations and Consumer Product Responses," The Journal of Marketing, Vol. 61, No. $1,68-84$.

Chapman, Joe dan Russ Wahlers (1999), "A Revision and Empirical Test of the Extended PricePerceived Quality Model", Journal of Marketing, p.53-64.

Cobb-Walgren, Cathy, Cynthia A. Ruble, dan Naveen Donthu (1995), "Brand Equity, Brand Preference and Purchase Intent", Journal of Advertising, 24 (3), p.25-40.

Fornell, Claes (1992), "A National Customer Satisfaction Barometer : The Swedish Experience", Journal of Marketing, Vol. 56, Jan, p.6-21.

Hawkins, Del I., Roger J. Best, dan Kenneth A. Coney (1998), Consumer Behavior :Building Marketing Strategy, Irwin/McGraw-Hill.

Hellier, Phillip K., Gus M. Geursen, Rodney A. Carr, dan John A. Rickard (2003), “Customer Repurchase Intention : A General Structural Equation Model", European Journal of Marketing, Vol. 37/11, p.1762-1800.

Kotler, Philip dan Armstrong, Gary, 2001. Prinsip-prinsip Pemasaran, Jilid 1, Alih Bahasa: Damos Sihombing, Edisi Kedelapan, Jakarta : Erlangga.

Li, Chieh-Lu dan Joohyun Lee (2001), “Dimensions of Service and Their Influence on Intention to Repurchase", Department of Leisure Studies Penn State University.

Parasuraman, A., Valerie A. Zeithaml, dan Leonard L. Berry (1988), “A Multiple Item Scale for Measuring Consumer Perception on Future Research", Journal of Marketing, Vol. 49/1.

Söderlund, Magnus dan Mats Vilgon (1999), "Customer Satisfaction and Links to Customer Profitability : an Empirical Examination of the Association Between Attitudes and Behavior", Working Paper Series in Business Administration, No. 1.

Sugiyono, 2004. Metode Penelitian Bisnis, Cetakan Keenam, Bandung: Alfabeta.

Ward, Steven, William Chitty, dan Brendan Achard (2005), "Brand Equity in an Online World", Journal of Internet Business, Vol. 2 (April).

Tjiptono, Fandy . (2014). Pemasaran Jasa. Jakarta: Gramedia Cawang. Zeithaml, V. A. (1988), "Consumer Perceptions of Price, Quality, and Value : A Means-End Model and Synthesis of Evidence", Journal of Marketing, Vol. 52, July, p.52-54.

Zeithaml, V. A. dan Mario Jo Bitner (1996), Service Marketing, McGraw-Hill Companies Inc., New York. 


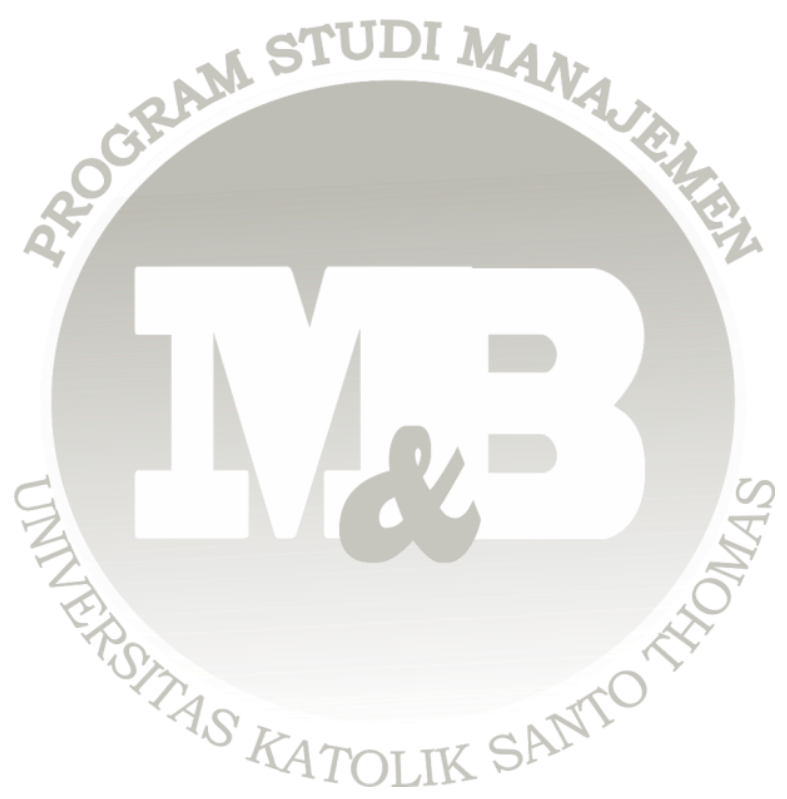

